\title{
Benign transient lymphangiectasis (sclerosing lymphangitis) of the penis
}

\author{
P. HUTCHINS,* E. M. C. DUNLOP, AND P. RODIN \\ From the Whitechapel Clinic of The London Hospital, London
}

SUMMARY The literature on benign transient lymphangiectasis of the penis (BTLP) was reviewed; reports of 45 cases were collected and a further series, comprising 21 cases, is presented. Both the published and present series support the view that BTLP is associated with recent sexual activity; little support is given for an infective cause and it is confirmed that BTLP is a benign, self-limiting condition presenting in the sexually active man between 20 and 40 years old. There can be recurrences, and susceptibility to them may be encouraged by circumcision in which disturbances of lymphatic drainage may play a part. As so few cases have been reported and few were diagnosed in the present series these comments can only be pointers to further studies. The descriptions in six histological examinations, the reports as 'phlebitis' of apparently similar lesions, the report of 'sclerosing lymphangitis' in other sites, and the known histological similarity between veins and lymphatics suggest that 'sclerosing lymphangitis' is too specific a term. Until further knowledge is available, we suggest that this condition is best regarded as simple dilatation of a lymphatic vessel-namely, lymphangiectasis. As the condition is both benign and transient we propose the term benign transient lymphangiectasis of the penis for the condition formerly known as sclerosing lymphangitis.

\section{Introduction}

The presence of a painless, hard, nodular, translucent cord that suddenly appears in the penis and is usually confined to the coronal sulcus (Figure) has been known by various names (Table 1).

Of these perhaps the most usual has been 'sclerosing lymphangitis of the penis', but benign transient lymphangiectasis of the penis (BTLP) seems a better term and will be used here. BTLP is said to be rare and may present to doctors unfamiliar with it; indeed one of us ( $\mathrm{PH})$ first encountered it in an Emergency and Accident Department. This led to a retrospective study of BTLP and a comprehensive review of the literature. The information so collected is presented with a series of our own recent and earlier unpublished cases to stimulate further studies.

\footnotetext{
*Now at Queen Elizabeth Hospital for Children, London

Address for reprints: E. M. C. Dunlop, Whitechapel Clinic of The London Hospital, London E1 1 BB

Received for publication 6 May 1977
}

Table 1 Nomenclature

\begin{tabular}{|c|c|c|}
\hline Name & Author & Date \\
\hline $\begin{array}{l}\text { Non-venereal lymphangitis of the } \\
\text { penis (gonorrhoeal pseudochancre) }\end{array}$ & Hoffman & 1923 \\
\hline \multirow{2}{*}{$\begin{array}{l}\text { Non-venereal plastic lymphangitis of } \\
\text { the coronal sulcus }\end{array}$} & Hoffman & 1938 \\
\hline & Boulle et al. & 1963 \\
\hline $\begin{array}{l}\text { Circular (non-venereal) lymphangitis } \\
\text { of the coronal sulcus }\end{array}$ & von Berde & 1937 \\
\hline \multirow{2}{*}{ Circular indurated lymphangitis } & Gougerot and Blum & 1939 \\
\hline & Boyd & 1970 \\
\hline Transient penile lymphangiectasis & $\begin{array}{l}\text { Dunlop (unpublished } \\
\text { observations) }\end{array}$ & 1953 \\
\hline Lymphangiectasis of the penis & Kondo and Wanatabe & 1954 \\
\hline Lymphocele & King and Nicol & 1975 \\
\hline \multirow[t]{3}{*}{ Sclerosing lymphangitis of the penis } & Shigematsu et al. & 1965 \\
\hline & Lassus et al. & 1972 \\
\hline & Stolz et al. & 1974 \\
\hline \multirow{11}{*}{$\begin{array}{l}\text { Non-venereal sclerosing lymphangitis } \\
\text { of the penis }\end{array}$} & Nickel and Plumb & 1962 \\
\hline & Miki et al. & 1966 \\
\hline & Rook et al. & 1968 \\
\hline & Boyd & 1970 \\
\hline & Kandil and Al-Kashlan & 1970 \\
\hline & Greenberg and Perry & 1972 \\
\hline & Lassus et al. & 1972 \\
\hline & Janula and Janasová & 1973 \\
\hline & Matheis & 1972 \\
\hline & & 1973 \\
\hline & Fiumara & 1975 \\
\hline $\begin{array}{l}\text { Benign transient lymphangiectasis of } \\
\text { the penis (BTLP) }\end{array}$ & Present series & 1977 \\
\hline
\end{tabular}




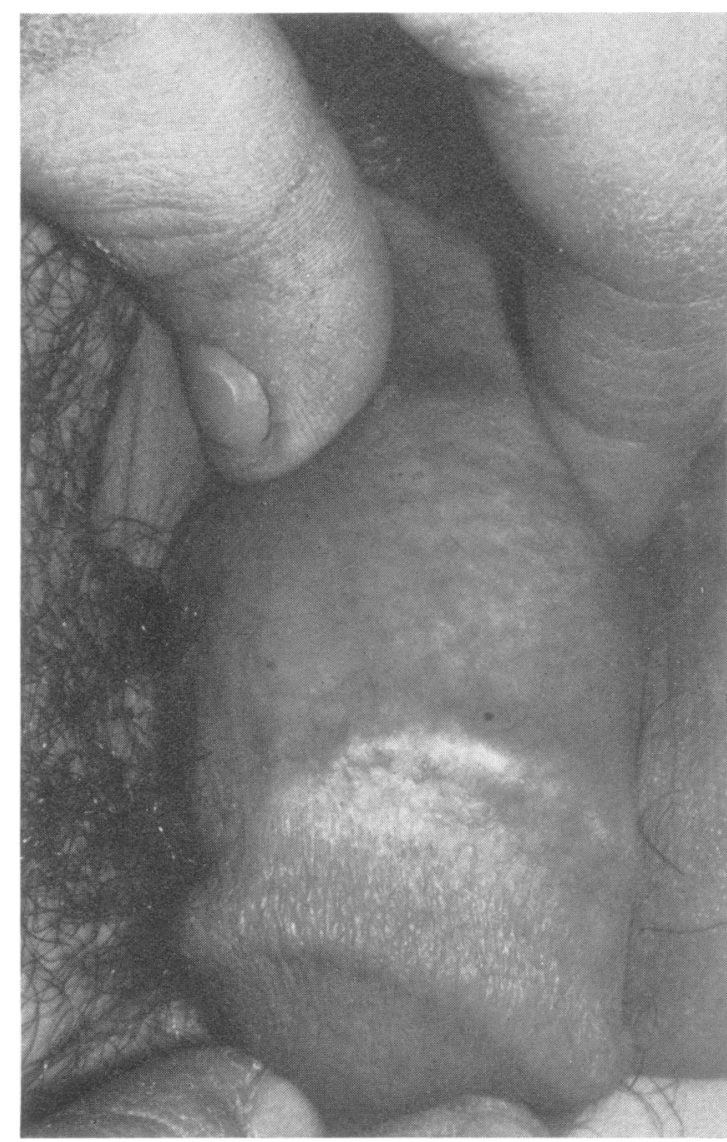

Figure Benign transient lymphangiectasis of the penis $(B T L P)$ in Case 8.

\section{PUBLISHED CASES}

Table 2 summarises the 45 cases recorded in the literature including those of six patients said to have lesions in non-penile sites or in whom the lesions were thought to be phlebitic. Since this report was prepared another six cases have been reported (McMillan, 1976).

The condition occurred in patients aged between 24 and 60 years (mean 32) with only one older than 50 years, and in patients in various occupations.

Marital state was recorded in only 20 cases. Nine patients were married and 11 single; the sexual partner was the wife in five cases, a regular partner in two, and a casual partner in 10 . Recent prolonged or frequent coitus was admitted by 12 patients; there was no definite history of trauma, although recurrence arose in two patients after strenuous coitus.

Onset of the condition was noticed during coitus by two patients, within 24 hours of coitus by seven patients, and within seven days by six. They presented for medical advice within hours to six weeks from onset.

Duration of the lesion was between three weeks and four months in the 37 cases in which this was recorded (mean 41 days). There were recurrences, in two patients after strenuous coitus, which lasted for 21 days in each (Greenberg and Perry, 1972; Lassus et al., 1972).

Nine patients had histories of sexually transmitted disease: gonorrhoea in five, non-specific urethritis (NSU) in two, secondary syphilis and chronic prostatitis in one, and lymphogranuloma venereum in one. Concurrent infections had been present in nine patients: gonorrhoea in four and NSU in five.

Biopsy was performed in eight cases, including those of 'phlebitis', a lesion on the labium minus, and a lesion on the lip.

Various treatments were used for BTLP, including excision biopsy, aspiration, penicillin, tetracyclines, fungicides, topical corticosteroids, anti-inflammatory agents (Fiumara, 1975), wet compresses, anti-viral agents (Kandil and AlKashlan, 1970), and the advice to be sexually abstinent.

\section{PRESENT CASES}

Table 3 gives details of 23 episodes of BTLP diagnosed in 17 patients who attended this clinic between January 1968 and April 1975, also of four patients seen between 1951 and 1953 by one of us (EMCD). Numerical totals and means are derived from those cases in which definitive information was available. The ages of the patients varied between 18 and 51 years (mean 29) with only one patient older than 39 . They had a wide variety of occupations.

Three patients were married, two were divorced, and 16 were single. The sexual partners were casual contacts, except for two cases in which contact was marital only, and four in which it was with a regular partner only. Penile trauma had occurred in two cases: a fraenal tear in one (Case 12), and repeated urethral irrigations in another (Case D).

Onset of the condition was noted by one patient during erection, by five within 24 hours of coitus, and by seven within seven days. They presented to a doctor between a few hours and 21 days after onset.

Duration (where this could be defined) varied between three and 40 days (mean 15). Recurrence other than immediately after aspiration, occurred in six patients and lasted for between seven and, in one case, more than 60 days; in the latter this was associated with an abscess of Tyson's gland. 
Table 2 Summary of published reports of benign transient lymphangiectasis (or sclerosing lymphangitis) of the penis

\begin{tabular}{|c|c|c|c|c|c|c|c|}
\hline \multirow{3}{*}{$\begin{array}{l}\text { Author } \\
\text { Hoffman }\end{array}$} & \multirow{3}{*}{$\begin{array}{l}\text { Date } \\
-192 \overline{23}\end{array}$} & \multirow{3}{*}{$\begin{array}{l}\text { No. } \\
\text { of cases } \\
\overline{2}\end{array}$} & \multirow{3}{*}{$\begin{array}{l}\text { Age } \\
\text { range } \\
\text { (years) }\end{array}$} & \multicolumn{2}{|c|}{ Sexually transmitted disease } & \multirow{2}{*}{$\begin{array}{l}\text { Total } \\
\text { duration } \\
\text { (days) }\end{array}$} & \multirow{2}{*}{ Special findings } \\
\hline & & & & \multirow[t]{2}{*}{ Previous } & \multirow{3}{*}{$\begin{array}{l}\text { Gonorrhoea } \\
\text { in both } \\
\text { NGU-1 }\end{array}$} & & \\
\hline & & & & & & & \\
\hline von Berde & 1937 & 4 & $30-34$ & & & $16-25$ & $\begin{array}{l}\text { One contact examined, no abnormality } \\
\text { found }\end{array}$ \\
\hline Hoffman & 1938 & 1 & 49 & $\begin{array}{l}\text { Gonorrhoea } \\
8 \text { years earlier }\end{array}$ & NGU & 29 & \\
\hline Gougerot and Blum & 1939 & 1 & 43 & $\begin{array}{l}\text { 'Simple } \\
\text { urethritis' }\end{array}$ & NSU & 84 & \\
\hline Kondo and Wanatabe & 1954 & 2 & $41-46$ & & & & Aspirate contained lymphocytes in both \\
\hline Braun-Falco & 1955 & 3 & $24-36$ & $\begin{array}{l}\text { Secondary } \\
\text { syphilis-1 }\end{array}$ & $\begin{array}{l}\text { Chronic } \\
\text { prostatitis } \\
\text { - same case }\end{array}$ & $21-35$ & $\begin{array}{l}\text { Clinically similar to BTLP. Multifocal. } \\
\text { Histology suggests phlebitis differing } \\
\text { from Mondor's disease. Associated with } \\
\text { tonsillitis, allergy? }\end{array}$ \\
\hline Nickel and Plumb & 1962 & 4 & $30-40$ & & & $14-56$ & Biopsy in one case \\
\hline Boulle et al. & 1963 & 1 & 29 & & & 147 & $\begin{array}{l}\text { STS and Frei negative } \\
\text { Associated ulcer. Previous topical } \\
\text { penicillin } \\
\text { Histology suggested phlebitis }\end{array}$ \\
\hline Shigematsu et al. & 1965 & 1 & 60 & & & & \\
\hline Miki et al. & 1966 & 3 & $29-49$ & & & $14-30$ & Excision biopsy in two cases \\
\hline Boyd & 1970 & 1 & 24 & & & & \\
\hline Kandil and Al-Kashlan & 1970 & 2 & $30-35$ & & & $32-42$ & $\begin{array}{l}\text { Biopsy in one case } \\
\text { Anti-viral agent tried } \\
\text { Onset soon after coitus }\end{array}$ \\
\hline Greenberg and Perry & 1972 & 3 & $20-28$ & Gonorrhoea-1 & & $21-70$ & $\begin{array}{l}\text { One case recurred } \\
\text { Onset soon after beginning coitus in } \\
\text { one case }\end{array}$ \\
\hline Lassus et al. & 1972 & 4 & $28-38$ & & & $21-56$ & $\begin{array}{l}\text { Recurrences in one case } \\
\text { Aspiration in two cases } \\
\text { Biopsy in one case }\end{array}$ \\
\hline Janula and Janasová & 1973 & 1 & 31 & & & & \\
\hline Stolz et al. & 1974 & 7 & $24-40$ & $\begin{array}{l}\text { Gonorrhoea-2 } \\
\text { NSU-1 } \\
\text { LGV-1 }\end{array}$ & $\begin{array}{l}\text { NSU-2 } \\
\text { Gonorrhoea-2 }\end{array}$ & $\begin{array}{l}\text { Not } \\
\text { known }\end{array}$ & $\begin{array}{l}\text { LGVCFT and Frei test positive in the } \\
\text { case of LGV } \\
\text { Biopsy in one case } \\
\text { Six patients professed frequent coitus } \\
\text { Duration? two years in one case } \\
\text { Lesion on upper lip }\end{array}$ \\
\hline Fiumara & 1975 & $\begin{array}{l}1 \\
3\end{array}$ & $\begin{array}{l}17 \\
20-28\end{array}$ & Gonorrhoea & & $\begin{array}{l}10 \\
14-28\end{array}$ & $\begin{array}{l}\text { Lesion on labium minus. Excision biopsy } \\
\text { All had coitus at least four times in } \\
\text { preceding } 24 \text { hours. One received } \\
\text { salicylate application }\end{array}$ \\
\hline
\end{tabular}

Eight patients had a history of a sexually transmitted disease: gonorrhoea in three, NSU alone in three, candidosis and NSU in one, and an abscess of a Tyson's gland in one. Concurrent conditions were present in 10 patients: gonorrhoea alone in one, secondary syphilis and gonorrhoea in one, NSU in four, and penile candidosis, genital warts, a Tyson's abscess, and urethral stricture were present in one patient each.

No biopsy was undertaken but aspirate was obtained in seven cases. Darkfield microscopical examination did not show organisms; there were few or no cells. Cultures for bacteria, Herpes simplex, Chlamydia, and for mycoplasmas were unsuccessful. Serological tests for syphilis gave negative results in all cases except in one of secondary syphilis and gonorrhoea (Case 17). Complement-fixation tests for lymphanogranuloma venereum gave negative results in three patients as did the Frei test in one.

No specific treatment was used other than aspiration which produced temporary resolution in six cases. Penicillin, streptomycin, and co-trimoxazole were used in one case each for coincidental infections; three patients had received local corticosteroid applications before presentation at the clinic. All patients were advised to abstain from coitus and masturbation until the condition had subsided.

\section{PATHOLOGICAL REPORT}

Biopsies have been reported in only six cases of BTLP with various findings (see Table 4). The common features were: thickening of the mural connective tissue of the lymph vessel, sometimes with fragmentation of elastic tissue (Miki et al., 1966; Kandil and Al-Kashlan, 1970), partial or total obliteration of the vessel lumen possibly by organising thrombus (Miki et al., 1966), and sparse evidence of chronic inflammation (Miki et al., 1966; Kandil and Al-Kashlan, 1970; Matheis, 1972).

Thickening of the vessel wall with obliteration of the lumen might explain our failure to puncture the lesion in two cases, although aspiration had been 


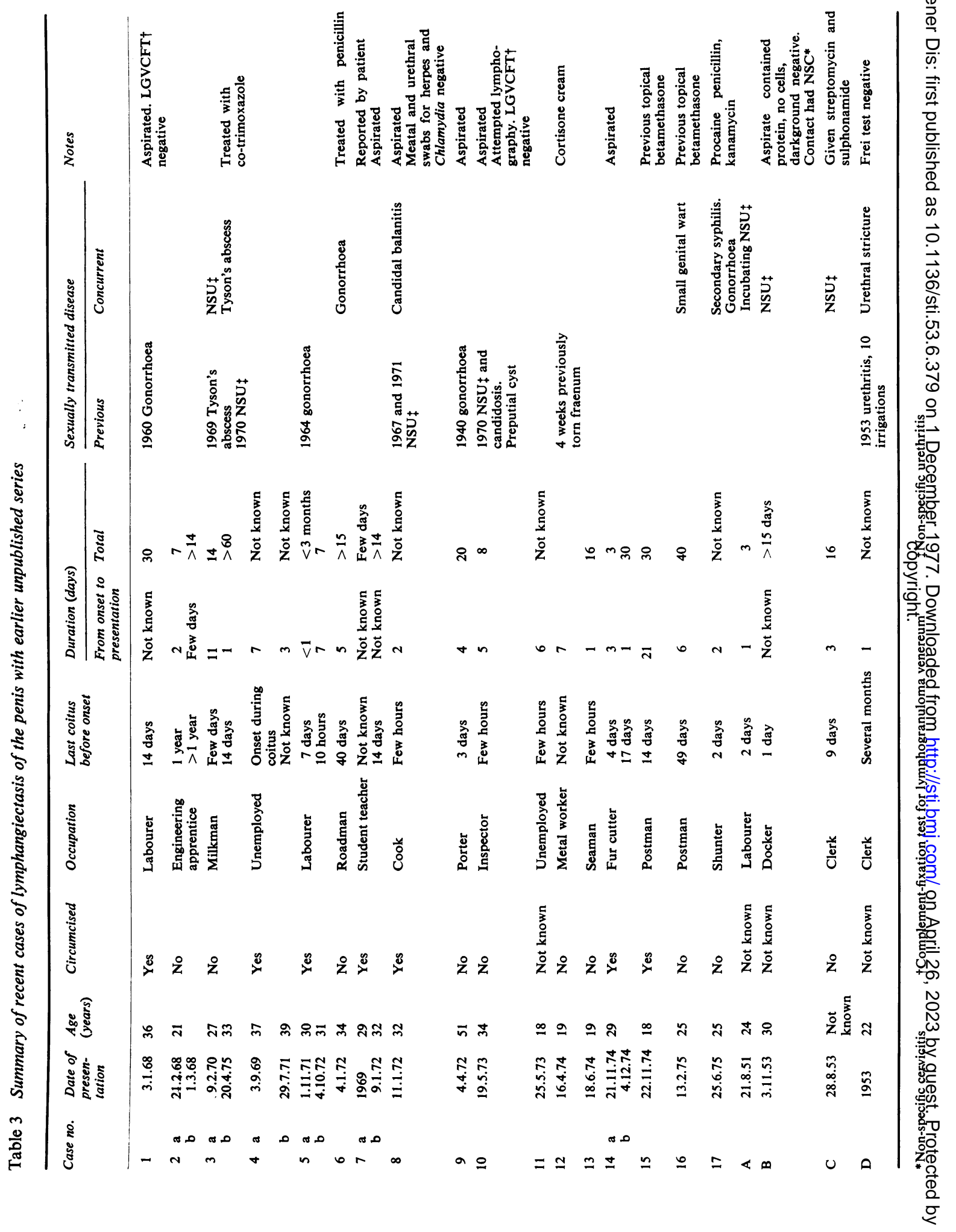


Table 4 Histological changes in BTLP

\begin{tabular}{|c|c|c|}
\hline Characteristics & Author & Date \\
\hline $\begin{array}{l}\text { 'Obliterating endophlebitis' with } \\
\text { endothelial swelling, intimal frag- } \\
\text { mentation and hyperplasia, some } \\
\text { perivascular fibrosis, some lympho- } \\
\text { cytes and histiocytes } \\
\text { Vessel containing erythrocytes. } \\
\text { Endothelial swelling; thickening of } \\
\text { wall; very few inflammatory cells- } \\
\text { said to be phlebitis }\end{array}$ & Braun-Falco & 1963 \\
\hline $\begin{array}{l}\text { Hypertrophy and some sclerosis of } \\
\text { wall. Connective tissue thickening. } \\
\text { Some inflammatory cells }\end{array}$ & Nickel and Plumb & 1962 \\
\hline $\begin{array}{l}\text { Partially thickened wall of a dilated } \\
\text { vessel, containing amorphous eosino- } \\
\text { philic material. No inflammatory } \\
\text { cells }\end{array}$ & Miki et al. & 1966 \\
\hline $\begin{array}{l}\text { In a second case, the above findings } \\
\text { with scanty elastic tissue, some fibrosis } \\
\text { and possible organising thrombus }\end{array}$ & & \\
\hline $\begin{array}{l}\text { Marked thickening, almost with total } \\
\text { occlusion and loss of differentiation } \\
\text { between intima and lumen. Some local } \\
\text { inflammatory infiltrate }\end{array}$ & Kandil and Al-Kashlan & 1970 \\
\hline $\begin{array}{l}\text { Marked thickening of wall with } \\
\text { oedema of connective tissue. A very } \\
\text { few inflammatory cells }\end{array}$ & Lassus et al. & 1972 \\
\hline $\begin{array}{l}\text { Penis. An unusually hypercellular } \\
\text { oedematous fibrous reaction in mural } \\
\text { connective tissue, fragmented elastic } \\
\text { lamina and some perivascular lympho- } \\
\text { cytes and histiocytes }\end{array}$ & Stolz et al. & 1974 \\
\hline $\begin{array}{l}\text { Labium minus. Very thickened wall, } \\
\text { obliteration of the lumen, sporadic } \\
\text { mononuclear cell infiltrate }\end{array}$ & & \\
\hline
\end{tabular}

successful in several of the published cases, and in seven of the present cases; aspiration resulted in disappearance of the lesion, albeit usually with rapid recurrence.

Of the generally recognised disorders of lymphatic vessels, the histological changes of 'sclerosing lymphangitis', and 'thrombolymphangitis productiva' (Pfleger et al., 1967) most closely resemble those of BTLP. However, the disappearance of the vessel on aspiration followed by rapid recurrence, the characteristic translucency, and the lack of chronic inflammatory changes suggest simple dilatation of the lymph vessels. In Most's classification of lymphatic swellings (Kondo and Wanatabe, 1954) this would be 'lymphangiectasis'a term already used for describing the character istic clinical entity (Dunlop, 1953, unpublished observations; Kondo and Wanatabe, 1954). This term may be more correct than sclerosing lymphangitis; or perhaps there may be two processes with sclerosis developing after a period of intermittent, recurrent, or persistent lymphangiectasis. It may be relevant that biopsy, two weeks after onset (Miki et al., 1966), showed fibrosis as a more notable feature, than did biopsy only a few days after onset (Kandil and Al-Kashlan, 1970).

Nickel and Plumb (1962) stated that their histological data 'demonstrated for the first time that the lesion is a result of a fibrous thickening of a large lymphatic vessel'. However, venous and lymphatic vessels can appear indistinguishable (Boulle et al., 1963; Lever, 1967). Boulle et al. (1963) cite their own case of apparent BTLP in which histology and the presence of intraluminal erythrocytes suggested 'phlebitis' rather than 'lymphangitis'. Braun-Falco (1955) described a clinical appearance identical with that of BTLP in which superficial cord-like thickenings were present in the penis, yielding serous fluid, and in which the biopsy appearance suggested 'obliterating endophlebitis'. Boulle et al. (1963) thought that this clinically resembled Mondor's phlebitis (Mondor and Bertrand, 1951), although it differed histologically; they suggested that hypersensitivity to infective agents was a possible cause. The penile lesions in these reports of phlebitis very closely resemble those of BTLP. Perhaps the clinical appearance of BTLP may be caused by venous or lymphatic lesions, or both. Lesions similar to BTLP have been reported in the upper lip of a man and in the labium minus of a woman, and Stolz et al. (1974) considered that infection was the most likely reason for these changes.

\section{Discussion}

\section{CAUSATION}

Most authors have accepted that BTLP is not caused by infection, ascribing particular importance to trauma during recent vigorous sexual activity, although they speculate about possible infective causes.

\section{TRA U MA}

Postulated traumatic causes include mechanical irritation that allows entry of pathogens into the mucosa, high coronal pressures during the plateau phase of sexual excitement (Matheis, 1972), traumatic obstruction of the vessels (Lassus et al., 1972), activation of resident viruses (Kandil and AlKashlan, 1970), and irritation by menstrual blood.

Possible undue trauma occurred in only two cases: one followed 10 irrigations for persistent urethritis (Case D, Table 3), and one followed one month after a fraenal tear (Case 12, Table 3). All patients had had coitus, and in many the onset of BTLP occurred a few days later. Particularly in the reports by Greenberg and Perry (1972), Lassus et al. (1972), Stolz et al. (1974), and Fiumara (1975), patients professed recent and frequent intercourse-up to six times a day. This was a less striking feature in our patients of whom 12 had had coitus within the week before onset of BTLP. 
If trauma during coitus or masturbation is responsible, then BTLP should surely be more common than it is. Naturally, it is particularly those patients who notice penile lesions after sexual activity who present to venereologists, and we wonder if the condition presents in other ways.

\section{INFECTION}

Suggested infective causes include viruses either 'resident' or freshly acquired (Kandil and AlKashlan, 1970), susceptibility after previous or concurrent sexually transmitted infections, and agents-such as members of the Chlamydia genus and mycobacteria.

The finding of a similar clinical lesion in the upper lip of a man after orogenital contact, and a lesion on the labium minus in which the histological findings resembled those of BTLP, suggest that the lesion may occur at non-penile sites because of infection (Stolz et al., 1974). However, the histological similarity between veins and lymphatics (Lever, 1967), the existence of Mondor's phlebitis, and the questions raised by Boulle et al. (1963) discussing the work of Braun-Falco (1955), suggest that the existence of multifocal BTLP with its implications of transmission has yet to be proved.

Previous episodes of sexually transmitted infection had occurred in nine of the published cases with concurrent infections diagnosed in nine cases; in our series seven patients (eight presentations) had had previous infections, and eight (nine presentations) had concurrent sexually transmitted infections. Such conditions would be expected in these patients, but no close relationship is apparent between the onset or recurrence of BTLP and previous or concurrent sexually transmitted diseases. Little information is available about sexual contacts in the published reports; examination of the sexual partners of our patients yielded no helpful information.

The failure to culture any infective agent from the aspirate obtained from our patients is perhaps not surprising in view of the few cells in the fluid; our failure to culture herpes simplex virus militates against this as a likely candidate for a resident virus activated or reactivated by trauma during sexual activity.

\section{CIRCUMCISION}

Trauma seems to play a part in some cases and perhaps a local anatomical abnormality is concerned. The normal anatomy of penile lymphatics (Lockhart et al., 1965) has not been studied by us but we made one unsuccessful attempt to inject contrast medium for radiography into the lumen of a lesion. Lymphography has been used in studies of other penile conditions (Jantet, 1962; Janca, 1972) and study of BTLP by this method is indicated.

It is remarkable that in no published report is circumcision specifically mentioned for it is possible that circumcision may disturb the normal lymphatic drainage of the glans and prepuce, making the trauma of coitus more likely to provoke BTLP. All of our patients except one were Caucasian, and in a random sample of our clinic attenders we would expect $25 \%$ to be circumcised (Taylor and Rodin, 1975). Information on this was recorded for 17 patients and seven $(41 \cdot 2 \%)$ were circumcised. Four of these seven patients suffered recurrences, as did two of the uncircumcised patients.

\section{INCIDENCE}

The seeming rarity of this condition has been stressed (Rook et al., 1968; Greenberg and Perry, 1972; Matheis, 1972). Certainly BTLP is likely to be missed by patients and doctors; it is often diagnosed incorrectly or not observed because of its painless, self-limiting nature. Reports include: four cases seen in six years (Nickel and Plumb, 1962), four cases seen in 18 months (Lassus et al., 1972), and three cases seen out of 10000 attenders (Fiumara, 1975). In our series 15 patients presented with this condition (of which four were recurrences) between January 1972 and April 1975, during whicho time about 22000 diagnoses were made for men. Our? cases seemed to occur in clusters, presumably because of improved recognition of BTLP by the clinic staff once a case had been demonstrated.

All patients in the present series had experienced coitus; they were between 18 and 60 years of age (mean 29); there are three cases reported in the literature and one in the present series in which the patient was older than 40. All our patients were heterosexual, all except one were Caucasian; this was in a clinic where $43 \%$ of men are non-Caucasian. Patients had a wide variety of occupations both in the published and present series. Initial presentation was usually to a venereologist, but six of our patients presented first to their family doctors and two to an Emergency and Accident Department.

\section{COURSE}

The lesion usually occurred within seven days of coitus; the patients presented for medical advice at any time from a few hours to weeks after the onset. Total duration, where this could be defined, was from three days to five months (mean 41 days in reports, and 15 days in our cases), but one case possibly lasting two years has been reported (Stolz et al., 1974).

Spontaneous resolution will occur in all cases; 
cure by excision biopsy is immediate, while aspiration produces resolution, usually temporarily. Various anti-bacterial, anti-inflammatory and corticosteroid preparations, as well as wet compresses, silver nitrate and diathermy, have been tried without beneficial effect.

\section{References}

Boulle, S., Civatte, J., and Maillard, P. (1963). Cordon induré non vénérien du prepuce? La lymphangite plastique de Hoffman seraitelle une phlébite. Bulletin de la Société française de dermatologie et de syphiligraphie, 70, 379-383.

Boyd, A. S. (1970). Non-venereal sclerosing lymphangitis of the penis. British Journal of Dermatology, 83, 632-633.

Braun-Falco, O. (1955). Zur Klinik, Histologie und Pathogenese der Strangförmigen, Oberflachlichen Phlebitiden. Dermatologische Wochenschrift, 132, 706-715.

Fiumara, N. J. (1975). Nonvenereal sclerosing lymphangitis of the penis. Archives of Dermatology, 111, 902-903.

Gougerot, H., and Blum, P. (1939). Lymphangite circulaire indurée de la verge. Annales des maladies vénériennes, 34, 503-504.

Greenberg, R. D., and Perry, T. L. (1972). Nonvenereal sclerosing lymphangitis of the penis. Archives of Dermatology, 105, 728-729.

Hoffman, E. (1923). Vortanschung primärer Syphilis durch gonorrhoische Lymphangitis (gonorrhoischer Pseudoprimäraffekt). Münchenen medizinische Wochenschrift, 70, 1167-1168.

Hoffman, E. (1938). Uber nicht venerische plastiche lymphangitis im sulcus coronarius penis mit umschriebenem Ödem. Dermatologische Zeitschrift, 78, 24-27.

Janca, K. (1972). Lymphography in diseases of the penis. International Urology and Nephrology, 4, 59-63.

Jantet, G. H. (1962). Direct intralymphatic injections of radioactive colloidal gold in the treatment of malignant disease. British Journal of Radiology, 35, 692-697.

Janula, J., and Janasová, B. (1973). Neverická sklerotizujici lymfangoitida penisu. Ceskoslovenská dermatologie, 48, 100-102.

Kandil, E., and Al-Kashlan, I. M. (1970). Non-venereal sclerosing lymphangitis of the penis. Acta dermato-venereologica, 50, 309-312.
King, A. J., and Nicol, C. S. (1975). Venereal Diseases, third edition, p. 330. Ballière Tindall: London.

Kondo, A., and Wanatabe, M. (1954). Lymphangiectasis of penis: A case report. Lymphatologia, 2, 147-149.

Lassus, A., Niemi, K. M., Valle, S-L., and Kiistala, U. (1972). Sclerosing lymphangitis of the penis. British Journal of Venereal Diseases, 48, 545-548.

Lever, W, F. (1967). Histopathology of the Skin, fourth edition, p. 34 Pitman Medical: Philadelphia.

Lockhart, R. D., Hamilton, G. F., and Fyfe, F. W. (1965). Anatomy of the Human Body, second edition, p. 661, Fig. 954; p. 668, Fig. 959. Faber: London.

McMillan, A. (1976). Lymphocoele and localised lymphoedema of the penis. British Journal of Venereal Diseases, 52, 409-411.

Matheis, H. (1972). Nicht venerische sklerosierende. Deutsche medizinische Wochenschrift, 97, 808-810.

Matheis, H. (1973). Lynfangite sclerosante non venerea del pene. Minerva medica, 64, 4967-4970.

Miki, H., Miki, R., Yamazaki, T., Ikeda, M., Kawashima, Y., and Fukushiro, R. (1966). Nonvenereal sclerosing lymphangitis of penis: Report of three cases. Japanese Journal of Dermatology, Series $B, 76,185-188$.

Mondor, H., and Bertrand, I. (1951). Thrombo-phlébites et periphlebites de la paroi thoracique anteriéure. Presse médicale, 59, 1533-1536.

Nickel, W. R., and Plumb, R. T. (1962). Nonvenereal sclerosing lymphangitis of the penis. Archives of Dermatology, 86, 761-763.

Pfleger, L., Kaindl, F., Mannheimer, E., and Thurnher, B. (1967) Histopathology of lymphatic vessels. In New Trends in Basic Lymphology. Proceedings of a Symposium held in Charleroi, Belgium, 11-13 July 1966, p. 138. Edited by J. M. Collette, G. Jantet, and E. Schoffeniels. Birkhäuser: Basel.

Rook, A., Wilkinson, D. S., and Ebling, F. J. G. (1968). Textbook of Dermatology, p. 1542. Davis: Philadelphia.

Shigematsu, S., Kuribayashi, T., and Minai, T. (1965). Sclerosing lymphangitis of the penis. Acta urologica, 2, 409-411.

Stolz, E., van Kampen, W. J., and Vuzevski, V. (1974). Sklerosierende Lymphangitis des Penis, der Oberlippe und des Labium minus. Hautarzt, 25, 231-237.

Taylor, P. K., and Rodin, P. (1975). Herpes genitalis and circumcision. British Journal of Venereal Diseases, 51, 274-277.

von Berde, K. (1937). Weitere Beiträge zur Kenntnis der nichtvenerischen Genitalerkrankungen. Dermatologische Wochenschrift, 105, 1532-1536. 